Trinity University

Digital Commons @ Trinity

Modern Languages and Literatures Faculty

Research

Modern Languages and Literatures Department

3-1992

\title{
Women's Images Effaced: The Literary Portrait in Seventeenth- Century France
}

Nina Ekstein

Trinity University, nekstein@trinity.edu

Follow this and additional works at: https://digitalcommons.trinity.edu/mll_faculty

Part of the Modern Languages Commons

\section{Repository Citation}

Ekstein, N. (1992). Women's images effaced: The literary portrait in seventeenth-century France. Women's Studies, 21(1), 43-56. doi:10.1080/00497878.1992.9978925

This Article is brought to you for free and open access by the Modern Languages and Literatures Department at Digital Commons @ Trinity. It has been accepted for inclusion in Modern Languages and Literatures Faculty Research by an authorized administrator of Digital Commons @ Trinity. For more information, please contact jcostanz@trinity.edu. 


\title{
Women's Images Effaced: The Literary Portrait in Seventeenth-Century France
}

\author{
NINA EKSTEIN \\ Trinity University, San Antonio
}

The literary portrait was extremely popular in France for a number of years during the mid-seventeenth century. ${ }^{1}$ With roots in salon society, the portrait became a genre in its own right during this period and was eventually incorporated in numerous other genres such as novels, memoirs, theater, and sermons. In this study, I will consider the close association between the initial vogue of portraiture and women, and examine the advantages and problems posed by the genre for women authors. I will trace the evolution of the literary portrait during the seventeenth century, in particular, the manner in which women were progressively dissociated from portraiture. Finally, I will consider how seventeenth-century portraiture is discussed in twentiethcentury criticism, focusing specifically on the role assigned to women in the history of the genre. The scope of this article will not allow for a rehabilitation of the mid-seventeenth-century portrait on aesthetic grounds. The focus will rather be the exploration of how a significant body of work, largely composed by women, has been denigrated and eclipsed in its own time as well as in our time for reasons which often seem more related to the sex of the authors than to the merits of the texts.

The literary portrait did not originate in the seventeenth century. Its roots go back to antiquity with such authors as Plutarch and Suetonius. In baroque literature, metaphor-laden descriptions of individuals are a frequent component of poetry. The popularity of the mid-century portrait dates from Mlle de Scudéry's Le Grand Cyrus (1649-1653), and flourished with the appearance of collections such as the Divers portraits (1659) and the Recueil de portraits et éloges (1659). The type of portraiture represented in these works is known by a variety of terms: the "portrait galant," the "portrait mondain," and the

Reprints available directly from the publisher

Photocopying permitted by licence only 
"portrait précieux." Why did this form become so strongly associated with women? In what ways does literary portraiture reflect concerns particular to women in the mid-seventeenth century? In order to answer these questions, it is useful to begin by examining the historical context in which they flourished.

The aptness of the association of women with the mid-century vogue of portraiture is easily demonstrated by examining the gender of both the authors and objects of portraiture. In Mlle de Montpensier's Divers portraits, only 8 men contribute to the 59 portraits, and 43 of the portraits describe women. Faith Beasley notes the preponderance of women in the portraits: "the volume in fact appears to be dedicated to depicting women within society, and to valorizing the salon milieu and female initiative" (527). In Barthelemy's 1860 edition, La Galerie des Portraits, ${ }^{2}$ only 39 of the identified 112 portraitists are men, as are 32 of the 157 objects. Women dominate every category: $80 \%$ of the objects, $65 \%$ of identified portraitists, $73 \%$ of selfportraits. In the case of Mlle de Scudéry's novels, Le Grand Cyrus and Clélie, Rebecca Tingle Keating notes that of the approximately 180 portraits, there are more than one and a half times as many depictions of women as of men (138). ${ }^{3}$ Even the portraits found in the letters of Madame de Sévigné (which do not properly belong to this period, as their chronology extends far beyond the moment of the portrait's popularity) depict women more frequently than men (see Verdier 71). There is no question that in the popular imagination and in the texts themselves the "portraits mondains" are strongly associated with women.

The vogue of portraiture takes place not merely in the isolation of the salon or in the fairyland of the heroic novel, but also within the context of a particular political reality. This reality - the Regency of Anne d'Autriche, the Fronde, the approach of absolutism, and the growing impotence of the nobility - suggests two opposing interpretations concerning the significance of the portrait form. Sandra Dijkstra presents literary portraits as products of the nobility, rather than specifically of women, a symbolic revolt against the erosion of the nobility's power (22-24; see also Harth 70). The issue of women's discourse is not absent, however, merely implicit; the nobility's loss of power represents castration, a feminization of the nobility after their defeat in the Fronde. They now share in the traditional political powerlessness of women and thus are reduced to a passive, self-reflective activity: portraiture. In a more positive light, the historical context suggests an empowerment of women, implying the strength to create a literary genre. In this interpretation, the political power of a woman, Anne d'Autriche, may be linked to the presence of a distinctly female voice. According to Domna Stanton, the period of disorder exemplified by the Fronde and the Regency is associated with 
female deviation (125; see also Plantié 353). Portraiture reigns at a moment when men do not control political reality and thus cannot fully control discourse. The political context therefore suggests a link between portraiture and women in either interpretation. Differences arise concerning whether this link is to be coded positively or negatively.

The literary portrait may also be situated by its close ties with preciosity. Certain stylistic and linguistic features are shared by both (see Keating 284), as well as a focus on the particular rather than the general (Beasley 531; Harth 105). And, of course, both preciosity and portraiture are commonly associated with women, in fact with specific women. Finally, both have been mercilessly ridiculed and satirized. While an association between the two is often made, it has not been examined in any depth. The links between the literary genre and the vaguely constituted social/intellectual group are complex and deserve more attention.

Portraiture constituted a positive form for women in many ways. Most obvious is the simple fact that it gave many women a voice. Women were allowed to express themselves, describing others or themselves. There seemed to have been no hesitation to commit pen to paper, and the widespread activity of writing such descriptions gave rise to many published portraits (Plantié 229-66). The importance of such expression of the self should not be underestimated. Women thus assumed the role of author/authority and thereby claimed knowledge and expertise. ${ }^{4}$

Literary portraits were traditionally used, whether in painted or written form, to glorify and ennoble the object (Harth 83-87, 120). Consider, for example, the heroic painted portraits of the early seventeenth century: individuals were depicted as specific mythological heroes (e.g., Rubens portrayed Marie de Medici as the Roman war goddess Bellona) in order to assert the individual's glory. Such portraits were in no way perceived as ridiculous. Furthermore, by their very nature, portraits are positive because they are a gesture of immortality. The individual is preserved in a portrait, beyond the vicissitudes of time or events. ${ }^{5}$

Finally, the vast majority of the portraits of this period are positive in tone. Women describe and are described in highly favorable and even idealized terms. While sometimes immoderate in their praise, portraitists propound a positive image of each other. The literary portrait provided a means for women in the seventeenth century to speak out while establishing their identity in an enduring and affirmative fashion.

The association of this group of portraits with women is in part based upon context. The vogue of portraiture has its roots in salon society, a milieu strongly associated with women (Orenstein 78). Indeed, seventeenth-century 
salons, while open to men, were led by women. For privileged women of the seveneenth century, attendance at a salon is an activity that had validity only insofar as it was repeated. The experience acquired meaning not through goal-oriented activity, but rather through the repeated act of conversation with and observation of one's peers. The portrait, lacking in chronology and linear narrative thrust, may be viewed as the written record of such observations.

While the literary portrait is often accused of being formulaic, in fact its structure is unsettlingly open. Physical description traditionally proceeds from head to toes, but the placement of such description itself within the portrait is completely at the author's discretion. There are no norms for how a portrait is to begin, and certainly none for an ending (a portrait, being a description, is an inherently open-ended form) (Hamon 47). The traditional structure of beginning-middle-end ${ }^{6}$ is absent. Plantié notes a lack of concern for issues of structure: "if the writer forgets a comment along the way, $\mathrm{s} / \mathrm{he}$ simply picks up the subject again; writers repeat what they have already said; they ramble on; it's the revenge of disorder on order, of conversation on oration, of free expression on rhetoric" (292). The literary portrait itself becomes progressively more independent during this period, even within the context of a novel, thereby undermining larger structural unity. Maurice Lever notes how the portrait begins to break loose from narrative action in Le Grand Cyrus, and how that independence is even greater in Clélie: "the portraits are isolated, separated by the narrative with which they sometimes have only distant and vague ties" (128). ${ }^{?}$

It must be admitted at this point that the portrait, considered both as form and as historical phenomenon, offers serious problems for women as well as advantages. These problems are closely tied to the very advantages we have discussed. Women find a voice in the portrait form. But the strength of their voice, and consequently, of their authority, is compromised to some degree by the ambiguity of the status of the text: are the portraits public or private discourse? Public discourse involves communicating a text to a broad audience; specifically, in this case, publishing one's text under one's own name. Private discourse is highly restricted in audience, destined for a few known readers. Literary portraiture as practiced in the mid-seventeenth century has strong links to private discourse; the connection to public discourse is often undermined by the circumstances of publication or even by the author herself.

The private side of portraiture is not difficult to perceive. Its vogue took place within the confines of the salon, an essentially intimate environment, however often copied, and whatever the social milieu. The members of the 
group described each other for each other. Even the portraits in Mlle de Scudéry's novels can be said to be private insofar as the referents of each portrait are known only to a select group of initiates.

In the Divers portraits, the writers often excuse the fact that they are writing by insisting that they were commanded to do so. Plantié recognizes the significance of such statements: "the order to paint or to paint oneself is often essential; it alone frees the writer from timidity, from modesty; it alone gives free rein to the secret desire to write which is usually checked by the rules of society, of civility" (270). ${ }^{8}$ Writers not only offer excuses, but they also pretend that their discourse is private. The classic pretense is that the portrait is part of a letter they are writing. Letters are a lorm of essentially private discourse.' Once again, this strategy is associated with women: over three-quarters of those who feign to be writing a letter in the Divers portraits are women.

While "the wall between public and private is a strong and serious one" (Juhasz 64), the women writers of portraits in the mid-seventeenth century are situated in a kind of grey area between the two, making concessions to both. On the one hand, Mlle de Montpensier hid behind her male secretary Segrais in publishing the Divers portraits; on the other hand, she did choose to publish the collection. Of course, "publish" may be a strong term given the situation: only 30 copies (or 60, depending on the version of events accepted) (Mayer 138) were produced! A very private public indeed! Similarly, Mlle de Scudéry published her novels, but generally they appeared under her brother Georges's name (Adam 2:133). ${ }^{10}$ Thus, in the "portrait galant," discourse plays at being both public and private at once, as though violating a boundary while appearing to remain restrained and modest.

As we mentioned earlier, portraits provided a means of presenting a positive image and identity for women. But the favourable tone itself led to the second problem: flattery. The vast majority of the portraits in both Scudéry's novels and Mlle de Montpensier's collection are highly flattering. And the overabundance of flattery led to considerable criticism and ridicule. The problem is almost inevitable in portraiture. Indeed, the portrait form does not lend itself to a balanced consideration, let alone to an objective one. Consider the following brief examples from the Divers portraits:

There is no one who does not notice that you have a beautiful figure, rich and wellproportioned, that your body is majestic and clearly belongs to an individual of exalted birth; that you have a noble, sweet, and charming air about you, that your hair is ash-blonde and so beautiful that one almost never sees any to match it. (\#44)

Her teeth can scarcely avoid being lovely,

For every day she puts in new ones;

And since she has produced fourteen or fifteen children,

Her breasts are less triumphant; 
Neophile is not stocky,

She has hardly any fat on her at all;

Her hands are not greatly appreciated, nor are her arms. (\#103)

The discourse will tend either toward praise and flattery, or toward the negative, resulting in denigration and satire. Description favors such extremes because of the absence of formal limits (Cobley 399; Hamon 15): the text may extend indefinitely, which a number of the portraits seem to do. Even in those cases where the portraitist seeks to be even-handed, the length of the portrait, its leisurely discussion of the physical and moral qualities of the object, and its utter gratuitousness, give rise to the accusation of vanity.

Linked to flattery as a problem is monotony. The portraits are highly formulaic in nature. André Bertière states the issue well: "a so strongly stereotyped composition, progressing by means of the juxtaposition of parallel statements on themes known ahead of time, condemns the genre to a monotony that is further exacerbated by a tendency toward idealizing" (477). The portraits of this period typically touch upon such subjects as facial traits, bearing, hands, figure, friendship, ambition, temperament, interest in reading, writing, speaking, attitude toward lies and gossip, judgment, and religious piety. Very few deviate strongly from the conventional formulas. As in the case of public/private discourse, there seems to be movement in opposite directions: on the one hand, women are asserting themselves by merely writing portraits, and the image they present is a positive one. On the other hand, there seems to be considerable anxiety about making oneself conspicuous. The spirit of conformism is strong and many of the portraits sound unsettlingly similar.

Literary portraiture is also vulnerable to fragmentation. While the painted portrait leads to a totalization, the literary portrait, because it is a linguistic construct, presents a fractured view of the individual. ${ }^{11}$ Keating describes Scudéry's portraits as fragmented mirrors that have been pieced together again (145). According to modern feminist thought, however, fragmentation is the province of women, while unity is a traditionally masculine concept (Moi 160). Fragmentation may indeed be a natural state for women, particularly within the confines of a male world. What is disquieting within the portraits themselves is the avowed faith in unity, the belief that the portrait will indeed present the entire individual. ${ }^{12}$

The literary portrait is a form that was strongly appropriated by, and appropriate to, women in the mid-seventeenth century. It gave women a voice, a positive image, and effected a kind of legitimation of the self. In the literary portrait the self was a subject worthy of discussion, of a written text, and even of being published. At the same time, serious questions are raised by 
the genre: what is to be the image of women presented to an ever greater public? How much does the complex activity of portraiture need to be hidden under a veil of modesty? And an even more basic question: how does one adequately describe a human being?

Portraits did not simply disappear in the 1660 's, just as they did not appear out of nowhere ten years earlier. But they did change, appearing in different contexts and for different purposes. The portrait-collections were made up of independent texts. And while Mlle de Scudéry placed her portraits within the context of narrative action, they were in fact fairly independent of the novels in which they were found, ${ }^{13}$ particularly as many of the portraits were understood to depict real-world individuals given the names of fictional characters. As the vogue passed, however, portraits were used more and more within the context of other texts, especially memoirs, history, and sermons. These texts were also, in general, more public. While memoirs can be considered private insofar as they present events from the subjective and limited point of view of one person, they are also public documents. They are quasi-historical texts, based on verifiable events. Portraits are used therein to introduce and to situate characters. Both men and women wrote memoirs during this period and it is not clear which group predominated. Certainly, the more public the discourse, the more likely that the author was male. Mézeray's Histoire de France gives considerable space to portraits. The sermons by Bourdaloue and Bossuet, a form of discourse produced strictly for a public audience, contain many portraits as well. And finally, La Bruyère's Caractères is likewise aimed at a public audience.

The presence of women's portraits becomes more problematic as the century progresses. Mme de Sévigné's letters contain numerous examples, but her audience was intended to be private or at least highly restricted. The case of Mme de Lafayette is a curious one. Her talents as a portraitist were manifest in the portrait she did of Mme de Sévigné in Montpensier's Divers portraits. Her novels, however, contain no true portraits, only brief, vague, superlative-laden, abstract descriptions that do not touch upon specific features (see Meltzer 75; Sarlet 199). The source of much of the historical information for La Princesse de Clèves was Brantôme, and he employed numerous portraits in his relation of events; yet Lafayette chose not to do so (Sarlet 197). The portrait seems to have been displaced in Lafayette's novels from description to object: painted portraits play an important role in both Zaide and La Princesse de Cleves, ${ }^{14}$ but just as the princess is never described, neither is the portrait that Nemours steals. Portraits became objects, not discourse, in Lafayette's hands. 
The literary history of the portrait in the second half of the seventeenth century involves several superposed movements. The discourse shifts from private to public, and from women to men. Furthermore, it moves from Dattery to morality and from the particular to the general. While morality and ethics are not entirely neglected in the précieux portraits, they are hardly an important preoccupation. Piety is mentioned in a number of the texts in collections, and examples of moral edification can be found, such as the portrait of Mlle la comtesse de Brienne by Mlle de Montpensier (\#19 of the Divers portraits). The general concern with flattery, however, preempts any edifying value the portraits might have and leaves the object's virtues in vague, superlative terms. The satirical portraits, such as those found in Furetière's Roman bourgeois or La Bruyère's Caractères, by their criticism of the object, are more closely linked to ethical ends. ${ }^{15}$

The movement from the particular to the general duplicates on another level the movement away from preciosity toward classicism. The précieux portraits almost always refer to specific real-world individuals. Certainly referential specificity is maintained in histories and memoirs, but satirical texts such as Furetière's and La Bruyère's no longer have a specific referent. Furetière explicitly rejects the personal nature of the portrait in his Roman bourgeois: "do not waste your time trying to identify the person whose portrait or story you believe that you recognize in order to apply it to Monsieur X or Mademoiselle $Y^{n}$ (901). His protestations against reference are similar to those of La Bruyère: both deny the possibility of finding keys to identify their portraits. ${ }^{16}$ La Bruyère chronologically represents the final phase of the historical development of the literary portrait in seventeenth-century France. The genre has moved away from the personal and the intimate towards the general and the abstract. The traits he describes are shared by a number of individuals. La Bruyère's "caractères" generally depict types rather than specific individuals, and are didactic in intent, exposing rather than flattering (see Harth 150).

Literary portraits do not belong only to the seventeenth century. While they never again experience a period of popularity comparable to that in the 1650 's, the form persists and becomes vital to both history and the novel as they evolve in the following centuries. We have examined the general development of the portrait from the "portrait précieux" to the "caractères" of La Brryère, and have seen how a genre closely linked to women came to be associated with men. I would now like to consider the literary fortunes in the last hundred years of the first group of portraits, those associated with women.

Essentially, the portrait which developed in the middle of the century has 
been relegated to a lowly status. While literary historians are likely to mention the existence of "salon portraits," "portraits mondains," or "précieux portraits," specific examples are rarely given and the portraits are not anthologized. Rather they are denigrated as a group, trivialized, and dismissed. Dijkstra sums up the problem very well: "much less is generally known about the written portrait than about the Character. Unfortunately, critics, perhaps influenced by the fact that portrait-writing was, in part, un jeu de société, mostly engaged in and originated by women, have often dismissed this 'petit genre' as Lanson called it" (25). Indeed, the majority of the many negative statements made about these texts are based on the link between portraits and women. Dirk Van der Cruysse, for example, accuses the genre, or rather women, of being excessive:

It goes without saying that this literary fashion was cultuvated above all by women. . . That explains in part the often precieuse and affected quality of this literature. . . The excesses of this literature were ascribed entirely to women (41).

For Jacques Prévot, portraits are similarly limited:

Netther spontaneity nor personal observation can go beyond the level of nattery, of social conventions. Because it is not well established, the technique becomes pedantic, as does the vocabulary which is less rich than specialized, and less specialized than frozen (11).

Certainly, the précieux portraits are open to attack on the grounds of excess or of flattery; what is curious is the line of reasoning that these individuals follow, linking excess to women or flattery to a total failure of style. One tactic of recuperation of the literary portrait is to divide the genre into two groups, "that of tradition and that of the social world." Bertière leaves no doubt about the associaton of the masculine with the historical portrait and the feminine with the précieux portrait. ${ }^{17}$

The trivialization of the "women's portrait" takes some surprising forms. While devoting a lengthy thesis to the subject, Plantie states that one of the main interests that the "portrait mondain" has for modern readers is that it elicited attacks from some of the best writers of the century (such as Sorel, Molière, Furetière, and Boileau; all males) (13). This is hardly a compelling defense of the genre. Philippe Sellier, taking a different perspective, praises the role of women during the period and credits them with the rise of the portrait:

The feminine networks . . have played a decisive role in lessening the ngidity of the language, in refining psychological analysis, in the popularity of the portrait and of epistolary literature; they have contributed to the success of the most lively genre of the period, the novel ... What we are talking about here is the most dazzling moment for women in the history of French culture. 
However, to what does he attribute this success? "A 'white' hysteria", a "prénese neurosis" (119-20)!

The literary history of seventeenth-century France is conceived of and constructed in such a way as to either minimize the role of the portraits associated with women, or else to give credit for the literary portrait to men. Either way, women are essentially eliminated from the literary canon. For Bertière the "game of portraits" when balanced against the long male historical tradition, "is but an accident in the history of French literature, whose importance it would be foolish to overestimate" (478). The feminine discourse of the portrait is thus reduced to a meaningless episode in the long line of masculine literary history. A similar vogue in England, that of the Character, is associated primarily with male writers and is coincidentally not the butt of ridicule and trivialization. But in France, portraits are only valuable insofar as they rise above or deny their feminine origins. Prévot presents the portraits in Bussy-Rabutin's memoirs as just such an improvement: "in the place of these artificial and awkwardly idealized depictions, Bussy-Rabutin substitutes the work of an artist preoccupied with human truth" (11). Most interesting, in my opinion, is the following attempt to give the portrait solidly male origins:

The literary portrait, as a true genre, only came into beıng when it was detached from all context and developed independently, thereby attaining the same dignity as the painted portrait from which it borrows an entire pictoral, technical vocabulary (brush, pencil, shadowing, canvas, air, manner). The first to have conceived of the literary portrait in this fashion, according to A. Franz, was Georges de Scudéry. Undertaking a portrait of Cardinal Richelieu in about 1636, he invoked the name of Philippe de Champagne (1602-1674) who had painted a portrait of the cardinal, and whose fame as a portraitist was beginning to spread at that time. Despite all of our research efforts in the Bibliothèque Nationale, we have not been able to locate that independent portrait, which A. Franz found in a collection of Oeuvres diverses by Georges de Scudéry, located in the Royal Library of Dresden (Van der Cruysse 34).

The supposedly male origins of the portrait rest on an admittedly unverifiable assertion made in a 1905 dissertation by another male, Arthur Franz.

The most frequent attack against the "portrait précieux" is the most simple. The existence of portraits associated with women is acknowledged, but these women are relegated to the position of forerunners of the only portraitist worth reading, La Bruyère. This version of literary history dates back to the nineteenth century. Fournel calls Les Caractères "a collection of portraits raised to the most perfect point of the genre" (qtd. in Levrault 60). For Sainte-Beuve, the originality of La Bruyère

is not that of having created portraits, helter skelter, off the top of his head, as in a society game, as they were done before him, but of having made them concise, profound, clever, wellcomposed, satirical; in a word as only a great painter could (qtd. in Paquot-Pierret 67). ${ }^{18}$ 
Even Barthelemy, who edited the most recent version we have of the portrait collections, subscribed to this theory of historical progression toward the author of the Caractères: "La Bruyère was to make of this vogue a great literary genre" (iii). Modern critics read this particular chapter of literary history in precisely the same manner. For Peter Brooks the Caractères are the culmination of a long-standing social and literary trend, "a summa of seventeenthcentury portraiture, the end-term of a society's effort to portray, take stock of, and give meaning to itself" (77).

The message is simple: La Bruyère, a man, perfected what women began. There is no need to read these women portraitists, because their work is second-rate. Their efforts have been effectively eliminated from the literary canon, leaving only La Bruyère. ${ }^{19}$ Indeed the précieux portraits are quite difficult to find: there are no modern editions of the Divers portraits nor of any other collection. Scudéry's novels have been reissued, but not reedited and there is no index which might permit the reader to locate portraits.

It is not my intent to undertake a rehabilitation of women's portraits on aesthetic grounds. I certainly do not have the space to examine portraits individually. I can only state that a number of texts offer considerably more than a monotonous enumeration of flattering traits. Efforts at innovation were numerous and often successful. ${ }^{20}$ Nor do I seek to denigrate La Bruyère's genius for portraiture. I merely want to demonstrate how literary history has consigned a group of texts to oblivion.

Why has this occurred? The answer may have to do with gender differences in reading. The portrait is attacked for being monotonous. Is it possible that the perception of monotony is a male one, and that the women involved (as well as the many, many readers of Scudéry's novels) saw portraits as not monotonous at all? Is it possible that we read with a male sense of aesthetics, that the absence of the structuring principle of beginning, middle, and end makes it difficult if not unappealing to read a text? Perhaps the problem is not gender-linked, but rather a question of changes in ideology. The qualities described are no longer those we consider noteworthy in a person. Furthermore, the portraits are perhaps too topical in their reference to specific individuals, and thus lose their interest with the passage of time. May we simply say that, given our present literary preoccupations, this group of portraits is of far less interest in literary terms than are those of La Bruyère? Or perhaps these portraits might indeed be appreciated, if only they were available to be read?

There are no final answers, of course. I cannot help but believe that the association of women with these portraits is in part responsible for the sorry fortune they have encountered, both in the seventeenth century and since. 
These are texts in large measure by women and about women. Nadia Rigaud states: "a patriarchal civilization that undervalues women attributes importance and value to feminine actions only to the extent that they have something to do with men" (qtd. in Maclean 64). It is not surprising that male society showed little interest in portraiture until it had been transformed into a maledominated literary form.

A final footnote. The most extensive work on this group of portraits has been done by two women, Rebecca Tingle Keating ("The Literary Portraits in the Novels of Mlle de Scudéry") and Jacqueline Plantié ("La Mode du Portrait littéraire en France dans la société mondaine [1641-1681]"). In both cases, one in the U.S. and the other in France, the works appeared in the form of dissertations, both excellent, neither of which has ever been published, for whatever reasons. Furthermore, neither of these women has published work on the literary portrait. Their silence is a consistent continuation of the fate of seventeenth-century women's portraiture.

\section{NOTES}

1. What is meant by the term "portrait" is a description of an individual, including both external and internal traits, and extending for anywhere from a paragraph to several pages in length.

2. This edition combines the 59 portraits of the Divers portratls and the 98 portraits from the two competing editions of the Recueil des Portratls el Eloges.

3. The important role of women in this variety of literary portraiture does not of course preclude men from its practice, as Jacqueline Plantié notes (33). Bussy-Rabutin's Hisloire amoureuse des Gaules (1660) contains 21 portraits (16 of men and 5 of women) which are similar in style to those found in Scudéry's novels and the portrait collections.

4. Patricia Meyer Spacks states: "women dominate their own expenence by imagining it, giving it form, writing about t $^{n}$ (322). See also Ruth Carver Capasso, 97.

5. Dorothy Backer states that portraits "look beyond the accidental elements of a life, to present an abstract version of it, valid for eternity" (15). Wendy Steiner links the portrait with the ancient funerary statue, the "stele," in that both are gestures of preservation (5).

6. Edward Said calls this structuring principle "patnarchal" (162).

7. The translation is mine, as are all other translations unless otherwise indicated.

8. The excuse of an order to wnte is found in $17 \%$ of the portraits in the Divers portrails and $24 \%$ of those in the Galerie des portrants. The majority of those offering such excuses are women.

9. As Roger Duchêne has noted, Mme de Sévigné's letters became public against her will (vii).

10. It is curious that the portraits within her novels were universally thought to be of her hand and not of her brother's. See Keating, 107.

11. Roland Le Huenen and Paul Perron discuss the constraints inherent in description: "the very verbal discontinuity ..., through sequencing, deconstructs the original unity of the object" (714).

12. Keating states that Scudéry was mistakenly confident that the conscientious aggregation of 
numerous details would unfailingly reveal with perfect fidelity the whole person (175). See Michel Foucault on the belief in the adequacy of language durnng the seventeenth century (322).

13. As were her conversations, which she herself exerpted and republished later. I am grateful to James Gaines for this point.

14. John D. Lyons notes that in Zaide, a figure is effaced and a portrait misnamed, in the Prencesse de Cleves, a portrait is stolen and a painting is misappropriated (176).

15. Jean Serroy notes the similarity between the two authors and calls them both "moralistes" (628).

16. La Bruyère in his "Dıscours de réception à l'Académie françarse," describes the source of his "caractères:" "I took one trait from here and another from there;" (498).

17. "That of tradition: for the practice of the historical portrait, which the humanists borrowed from the Ancients, remained alive and healthy. That of the social world, which has deformed this tradition, and which, under the influence of the stylish salons, has given rise to the ephemeral fashion of the so-called 'precieux' portrait" (475).

18. Similarly for Lanson it was La Bruyère who "separated, isolated the portrait, giving it its artistic form and its philosophical value" (qtd. in Paquot-Pierret 4).

19. Joan DeJean speaks of a similar process with respect to the seventeenth-century novel. Women whose role in the development of the novel in France was capital (particularly Mlle de Scudéry) have been effectively eliminated from the literary canon. Only Mme de Lafayette is spared.

20. Plantie discusses the large number of varıations that Montpensier herself brought to the genre: the false self-portrait, the double portrait of the same person, the description of individuals who arc not attractive, the group portrait, the portrait describing somcone already described by another, etc. (173).

\section{WORKS CITED}

Adam, Antoine. Historre de la liltéralure franf̧aıse du dux-seplième siècle. 5 vols. Paris: Del Duca, 1968.

Backer, Dorothy. Precious Women. New York: Basic Books, 1974.

Beasley, Faith. "Rescripting Historical Discourse: Literary Portraits by Women." Papers on French Seventeenth Cenlury Literalure 14 (1987): 517-35.

Bertière, André. Le Cardinal de Retz mémonalisle. Paris: Klincksieck, 1977.

Brooks, Peter. The Novel of Worldliness. Princeton: Princeton University Press, 1969.

Capasso, Ruth Carver. "The Portrait in the Letters of Madame de Sévigné." Diss. Harvard L'. 1983.

Cobley, Evelyn. "Description in Realist Discourse: the War Novel." Style 20 (1986): 395-410.

DeJean, Joan. "Sapho's Leap: Domesticating the Woman Writer." L'Esprl créaleur 25.2 (1985): 14-21.

Dijkstra, Sandra. “La Grande Mademoiselle and the Written Portrait: Feminine Narcissism, Aristocratic Pride, or Literary Innovation?" Pacific Coast Philology 13 (1978): 19-28.

Duchêne, Roger. Introduction. Correspondance. By Madame de Sévigné. 3 vols. Paris: Gallimard, 1972. 1:vii-xix.

Foucault, Michel. Les Mots el les choses. Paris: Gallimard, 1966.

Furetière, Antoine. Le Roman bourgeots. Romanczers du XVIIe siècle. Ed. Antone Adam. Pans: Gallimard, 1958. 900-1104.

La Galerie des Portraits de Mlle de Montpensier. Ed. Edouard de Barthelemy. Paris: Didier, 1860.

Hamon, Philippe. Introduction à l'analyse du descripltf. Paris: Hachette, 1981. 
Harth, Erica. Ideology and Culture in Seventeenth-Century France. Ithaca and London: Comell University Press, 1983.

Juhasz, Suzanne. "Towards a Theory of Form in Feminist Autobiography: Kate Millet's Fear of Flying and Sita; Maxine Hong Kingston's The Woman Warrior." Intemational foumal of Woman's Studies 2 1979: 62-75.

Keating, Rebecca Tingle. "The Literary Portraits in the Novels of Mlle de Scudéry." Diss. Yale $\mathrm{U}, 1970$.

La Bruyère, Jean de. "Discours de réception à l'Académie française." Les Caractères. Paris: Garnier, 1962. 489-502.

Le Huenen, Roland and Paul Perron. "Reflections on Balzacian Models of Representation." Poetics Today 5 (1984): 711-28.

Lever, Maurice. Le Roman franfais au XVIle siècle. Paris: Presses Universitaires de France, 1981.

Levrault, Léon. Meximes el Portraits. Paris: Paul Mellottée, n.d.

Lyons, John D. "Speaking in Pictures, Speaking of Pictures. Problems of Representation in the Seventeenth Century." Mimesis. From Mirror to Method, Augustine to Descartes. Eds. John D. Lyons and Stephen G. Nichols, Jr. Hanover and London: University Press of New England, 1982. 166-87.

Maclean, Ian. "La Voie des précieuses et les détours de l'expression." Présences fémınınes. Eds. Ian Richmond and Constant Venesoen. Tübingen: Biblio 17, 1987. 47-70.

Mayer, Denise. "Recueils de portraits littéraires attribués à la Grande Mademoiselle." Bulletın du bibliophile 1969-70: 136-74.

Meltzer, Françoise. "Renaming in Literature. Faces of the Moon." On Refernng in Liletalure. Ed. Anna Whiteside and Michael Issacharof. Bloomington and Indianapolis: Indiana University Press, 1987, 70-83.

Moi, Toril. Sexual Textual Politics. Feminest Literary Theory. London and New York: Methuen, 1985.

Orenstein, Gloria. “Natalie Barney's Parisian Salon: The Savoir Faire and the Joie de Vivre of a Life of Love and Letters." 13th Moon 5.1-2 (1980): 76-94.

Paquot-Pierret, Léon. L'Art du portrat chez La Bruyėe. Brussels: Office de Publicité, 1948.

Plantié, Jacqueline. "La Mode du portrait littéraire en France dans la société mondaine (16411681)." Diss. Université de Paris IV, 1975.

Prévot, Jacques. "L'Art du portrait chez Bussy-Rabutin." Revue d'Histoire Lilléraire de la France 69 (1969): $1-12$.

Saïd Edward. Beginnıngs. New York: Basic Books, 1975.

Sarlet, Claudette. "La Description des personnages dans La Princesse de Clèves. XVIle siècle 44 (1959): 186-200.

Sellier, Philippe. "La Névrose précieuse: une nouvelle pléiade?" Présences fémınınes. Eds. Ian Richmond and Constant Venesoen. Tübingen: Biblio 17, 1987. 95-125.

Serroy, Jean. Roman et réalité. Les Historres comaques au XVIIe siècle. Paris: Minard, 1981.

Spacks, Patricia Meyer. The Female Imagination. New York: Alfred A. Knopf, 1975.

Stanton, Domna. "The Fiction of 'Préciosité' and the Fear of Women." Yale French Studies 62 (1981): 107-34.

Steiner, Wendy, Exact Resemblance to Exact Resemblance. The Liserary Portratture of Gettrude Stein. New Haven: Yale University Press, 1978.

Van der Cruysse, Dirk. Le Portrait dans les "Mémotres" du duc de Saint-Simon. Paris: Nizet, 1971.

Verdier, Gabrielle. 'Les 'Lucrèces' sortent du 'grenier': portraits de femmes dans les Lellres de Madame de Sévigné." Papers on French Seventeenth Cenlury Lileralure 8 (1981): 71-87. 